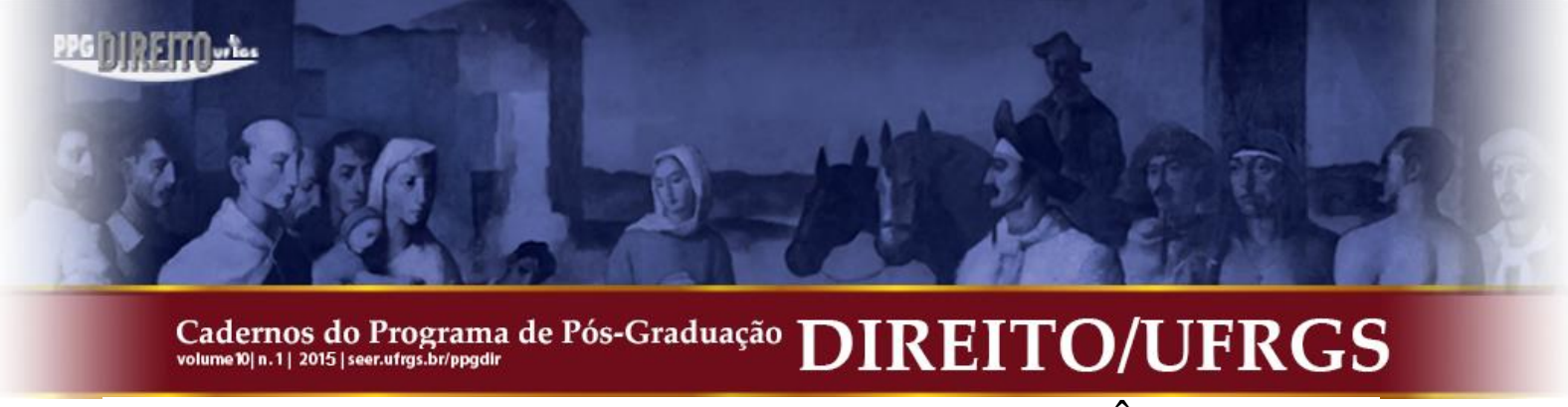

\title{
A NOVA AMPLITUDE DOS EMBARGOS DE DIVERGÊNCIA E SUA IMPORTÂNCIA NA UNIFORMIZAÇÃO DA JURISPRUDENCIA
}

\author{
THE NEW RANGE OF THE MOTION FOR RECONSIDERATION AND ITS RELEVANCE \\ FOR CASE LAW STANDARDIZATION
}

José do Carmos Góes*

Vinicius Silva Lemos**

\begin{abstract}
RESUMO: Este artigo versa sobre os embargos de divergência, em uma visão panorâmica, visando a sua apresentação de maneira geral, para posteriormente visualizar as suas modificações no Novo Código de Processo Civil. Os embargos de divergência referem-se a uma espécie de recurso judicial que deverá ser interposto no STJ ou STF. Isso se manterá, mas com novas possibilidades, com aspectos mais amplos e gerais, tornando a discussão ainda maior na forma recursal, mas no mesmo ínterim possibilitando a busca pela pacificação de entendimentos sobre os próprios embargos de divergência. $\mathrm{O}$ recurso terá papel fundamental no ideal do novo código de buscar a uniformização da jurisprudência, sua relevância para novas matérias e possibilidades recursais.
\end{abstract}

PALAVRAS-CHAVE: Embargos de Divergência. Uniformização da Jurisprudência. Recursos. Novo Código de Processo Civil brasileiro.
ABSTRACT: This article deals with the motion for reconsideration, in a brief overview, aimed at its presentation in general, in order to view subsequently its changes in the New Code of Civil Procedure. The motion for reconsideration refers to a kind of judicial appeal that ought to be filed before the Superior Court of Justice or the Supreme Federal Court. It will be maintained, but with new possibilities, with broader and more general aspects, enabling an even greater discussion on the appeal, but at the same time enabling a search for the settlement of understandings about the own motion for reconsideration. The appeal shall play a key role in the ideal of the new code to seek case law standardization, its relevance to new matters and appealing opportunities.

KEYWORDS: Motion for Reconsideration. Case Law Standardization. Appeals. Brazilian New Code of Civil Procedure.

SUMÁRIO: Introdução. 1. Embargos de divergência. 1.1. Finalidade e adequação. 1.2. Divergência atual e similitude fática como requisito de admissibilidade. 1.3. Do julgamento por turma de tribunal superior: impossibilidade em decisão monocrática. 1.4. A positivação do efeito interruptivo nos embargos de divergência. 2. O intuito da uniformização de jurisprudência. 2.1. Relevância e finalidade. 2.2. Meio repressivo para dirimir divergência. 3. A nova amplitude dos embargos de divergência. 3.1. A divergência em acórdão de mérito e sobre admissibilidade. 3.2. A ampliação para a competência originária dos tribunais superiores. 3.3. A divergência em direito material ou processual. 3.4. A ampliação do cabimento para acórdão da mesma turma. 3.5. A necessidade de fundamentação para negativa por distinção. Conclusão. Referências.

\section{INTRODUÇÃO}

O mundo jurídico brasileiro aguardava o novo código de processo civil, mudanças, adaptações, impacto no dia a dia jurisdicional, renovadas jurisprudências, posicionamentos, discussões e doutrinas jurídicas. Tudo acaba por ser novidade, mesmo quando o intuito foi melhorar, não se sabe o real valor da nova codificação.

Agora, com o texto aprovado, cumpre analisarmos os institutos e suas alterações, vislumbrar hipóteses e alternativas para uma melhor prática processual, dentro de análises

\footnotetext{
* Graduado pela Faculdade de Rondônia.

** Professor de Direito Civil e Processual Civil na Faculdade de Rondônia - FARO. Mestrando em Sociologia e Direito pela Universidade Federal Fluminense - UFF/RJ. Especialista em Direito Processual Civil pela Faculdade de Rondônia - FARO (2004). Graduação em Direito pela Faculdade de Rondônia - FARO (2003).
} 
acadêmicas para um melhor entendimento da legislação recente. $\mathrm{O}$ assunto em questão neste trabalho recai sobre os Embargos de Divergência que são um importante instrumento processual utilizado no judiciário brasileiro, à disposição das partes, do Ministério Público e terceiro prejudicado, dentro da mesma relação jurídica processual já existente para viabilizar a estabilização da jurisprudência interna dos Tribunais Superiores.

A prestação jurisdicional perfeita, aquela almejada na Constituição, determina que deve haver uma isonomia legal na busca dos direitos, devendo refletir em igualdade para todos os jurisdicionados quando buscam direitos semelhantes. Entretanto, é sabido que há percalços na busca e concretização desses direitos enquanto garantias fundamentais constitucionais, com decisões diversas, muitas vezes antagônicas sobre mesmos pontos.

Contudo, o Brasil é um país de dimensões continentais, constituído de estados federados que diariamente movimentam a máquina judicial, acionando para resolução de conflitos das mais diversas naturezas e envergadura, gerando uma diversidade imensa de decisões, necessitando de uma padronização de entendimento pelo STF e do STJ.

Assim sendo, o maior desafio a ser cumprido é o da uniformização da jurisprudência nos Tribunais Superiores de onde emanarão as decisões a serem cumpridas pelos demais tribunais de todo país. E isto só será possível por meio de uma pacificação dos entendimentos pelos Tribunais Superiores, com a tentativa de manter a jurisprudência uníssona, utilizando os diversos modos de composição de entendimentos, sendo um deles, os Embargos de Divergência que têm como finalidade precípua a consolidação da segurança jurídica que devem possuir os julgamentos do Supremo Tribunal Federal e do Superior Tribunal de justiça, onde uniformizar-se-á a interpretação e a explicação do direito.

Além do que, vale salientar que os Embargos de Divergência mantêm o caráter correcional que é próprio de todo recurso. Eles não só permitem que o acórdão embargado seja reformado, como também seja anulado, quando necessário, a fim de impedir a execução de um acórdão até que seja feita uma revisão de julgamento.

Isso equivale dizer que caso haja um dissenso entre acórdão de uma turma e, por sua vez, precedente de um outro órgão colegiado do mesmo Tribunal Superior, os Embargos de Divergência possibilitarão a eliminação da dita divergência, fazendo valer o entendimento majoritário dos componentes da Corte.

Com o novo código de processo civil, a importância e amplitude dos Embargos de 
Divergência alcançaram outro patamar, com maior vascularidade, mais hipóteses de cabimento, numa tentativa de ampliar seu raio da ação processual. Diante do exposto, a proposta aqui será demonstrar a não somente importância que há na utilização, via judiciário, do instrumento processual denominado Embargos de Divergência, para a perfeita harmonização da jurisprudência pátria, bem como os impactos da nova legislação no instituto, com as alterações legislativas realizadas.

\section{EMBARGOS DE DIVERGÊNCIA}

Os embargos de divergência estão no CPC 73, disposto no artigo 546, com o intuito de possibilitar a revisão de um acórdão de turma de tribunal superior (STJ ou STF) que divergir de outra turma do mesmo tribunal. Já no Novo CPC 15, os embargos são alocados para o final do código, no artigo 1043, mantendo a finalidade de impugnar acórdãos com resultados divergentes, em tribunais superiores.

No entanto, houve alteração no intuito de possibilitar maior amplitude aos embargos, assunto precípuo deste estudo, o qual alcançaremos no final. Conceituando a palavra embargos chegamos a acepção de "colocar empecilho", com o pensamento voltando ao processo de impedir o prosseguimento da demanda ou do seu andamento recursal. $\mathrm{O}$ ato de embargar acarreta um impedimento, seja no trânsito em julgado, seja na próxima possibilidade recursal, com a finalidade de cessar as controvérsias acerca das interpretações das normas jurídicas nos tribunais superiores para alcançar uma uniformização de jurisprudência ou de entendimentos.

Rapidamente relembrando a evolução histórica deste recurso, os embargos de divergência foram inseridos no ordenamento pela Lei n. 623 de 1949, acrescentando o parágrafo único ao artigo 833 do Código de Processo Civil de 1939 que afirma: "Além de outros casos admitidos em lei, são embargáveis, no Supremo Tribunal Federal, as decisões das Turmas, quando divirjam entre si, ou de decisão tomada pelo Tribunal Pleno".

Essa inclusão demonstra que desde antes da década de 1940, quando não exista ainda o STJ, somente o STF, já sofríamos com a presença de divergência de entendimentos no tribunal superior, não sendo um problema de nosso tempo, somente atualmente ampliado.

No CPC 73, o instituto recursal não foi reeditado, com total revogação, revigorado posteriormente pela lei 8.950/1994, inserido-o no artigo 546, com uma redação como: “é 


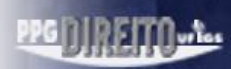

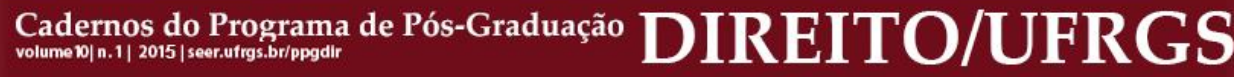

embargável a decisão da turma que: I - em recurso especial, divergir do julgamento de outra turma, da seção ou do órgão especiall; Il - em recurso extraordinário, divergir do julgamento da outra turma ou do plenário.”

Com a Constituição Federal criando o Superior Tribunal de Justiça, natural naquele momento da reedição dos embargos a ampliação de seu cabimento a este tribunal superior, transformando a forma recursal para ambos os tribunais superiores, como um instrumento jurídico para a resolução de divergência nestes tribunais, objetivando a uniformização e, não a simples promoção de reexame das questões de fato. Até a alteração proveniente do CPC 15 os embargos de divergência estavam delimitados da forma com que descrevemos, com importância para pacificar, de forma repressiva, a jurisprudência dos tribunais superiores.

\subsection{Finalidade e adequação}

Em linhas gerais, observa-se que há entendimento pacificado de que a finalidade dos Embargos de Divergência é a uniformização jurisprudencial interna dos tribunais superiores, eliminando, assim, as discrepâncias "intra muros", abolindo seus conflitos internos. Nesta esteira está circunscrito o pensamento de Leonardo Cunha e Fredie Didier Jr, quando afirmam que:

O objetivo dos embargos de divergência é obter uma uniformização de jurisprudência interna, no âmbito do STJ ou do STF. Obtida a uniformização, atende-se o segundo objetivo dos embargos de divergência: reformar/anular o acórdão embargado. Assim, providos os embargos de divergência, ao tempo em que se obtém a alteração do acórdão embargado, alcança-se se objetivo maior, que é a uniformização da jurisprudência interna do tribunal superior. (2013, p. 381)

Os tribunais superiores têm a função de pacificação do entendimento sobre a lei federal ou constitucional, se cumprisse esse dever, não necessitaria dos embargos de divergência.

Entretanto, diante de uma persistência em divergência de entendimentos, este recurso tem a finalidade de uniformizar a jurisprudencial interna destes tribunais superiores, abolindo seus conflitos internos. Há de se admitir que os tribunais superiores, por vezes, falham na sua função precípua, a de pacificar entendimentos, criando divergências internas que acabam por tornam mais complexo o direito do que, simplesmente, harmonizá-lo.

Para a devida utilização dessa modalidade recursal, no momento de adequação 


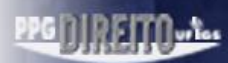 \\ Cadernos do Programa de Pós-Graduação volume $10 \mid$ n.1| 2015 | seer.ufrgs.br/ppgdir}

recursal necessita-se da existência de um processo com julgamento perante os tribunais superiores, STJ ou STF, com um resultado que, em pesquisa jurisprudencial, a parte encontre julgados do mesmo tribunal com outro entendimento, mesmo que seja em parte do acórdão ou em sua integralidade.

Para o cabimento recursal, há a necessidade de um julgamento em tribunal superior, com uma existência de divergência entre o acórdão daquele caso com outro acórdão de outro caso ou outros casos. Uma verdadeira configuração da divergência. Sem essa configuração, a situação não se torna adequada à interposição dos embargos de divergência.

\subsection{Divergência atual e similitude fática como requisito de admissibilidade}

$\mathrm{Na}$ interposição dos embargos de divergência, um requisito próprio e específico de admissibilidade salta diante da necessidade deste recurso. Se como dissemos, o intuito é sanar a divergência interna de um tribunal superior, com discrepâncias intramuros dos órgãos que julgam a mesma matéria, totalmente necessária a prova da existência da divergência, com a juntada no recurso, o acórdão paradigma, que serve de comparativo entre a decisão do processo recorrente e a da outra decisão com resultado diverso.

De antemão, para a interposição dos embargos se faz necessário, além da comprovação da divergência, que esta seja atual. Esta é primeira exigência para o conflito analítico. A atualidade dessa diferença de entendimento é necessidade para o cabimento recursal. Caso a divergência suscitada e comprovada, via acórdão antigo, pelo seu conteúdo desgastado, não caberão mais os embargos de divergência, pela própria ausência de conflito de entendimentos, como a súmula 168 do STJ, súmula 247 e 598 do STF:

\footnotetext{
Súmula 168 STJ - Não cabem embargos de divergência, quando a jurisprudência do tribunal se firmou do mesmo sentido do acórdão embargado.

Súmula 247 STF - O relator não admitirá os embargos da Lei n. 623, de 19. 02.1949, nem deles conhecerá o Supremo Tribunal Federal, quando houver jurisprudência firme do Plenário no sentido da decisão embargada."

Súmula 598 STF - Nos embargos de divergência não servem como padrão de discordância os mesmos paradigmas invocados para demonstrá-la, mas repelidos como não dissidentes no julgamento do recurso extraordinário".
}

Ultrapassada a comprovação da divergência e de sua atualidade, após, o recorrente deve em suas razões recursais, realizar o confronto analítico, a comparação entre os dois julgados, com a demonstração da similitude fática entre os dois casos, com resultados 


\section{vadingerpun \\ Cadernos do Programa de Pós-Graduação \\ volume $10 \mid$ n.1 | 2015 | seer.ufrgs.br/ppgdir \\ DIREITO/UFRGS}

diferentes para as mesmas situações e matérias jurídicas, cumprindo a sua função de suscitar a existência de uma divergência intra muros, demonstrando que "as hipóteses julgadas no acórdão recorrido e no acórdão paradigma devem conter similitude, a exemplo do que sucede no recurso especial interposto pela divergência jurisprudencial" (CUNHA, DIDIER JR, 2013 p. 378).

Fica compreendido que só haverá admissão dos embargos de divergência se ocorrer o cotejo entre o acórdão recorrido e o acórdão paradigma:

Ementa: PROCESSUAL CIVIL. EMBARGOS DE DECLARAÇÃO RECEBIDOS COMO AGRAVO REGIMENTAL. EMBARGOS DE DIVERGÊNCIA. DISSENSÃO JURISPRUDENCIAL NÃO COMPROVADA. AUSÊNCIA DE SIMILITUDE FÁTICA ENTRE OS CASOS CONFRONTADOS. COTEJO ANALÍTICO. NÃO REALIZAÇÃO. ART. 331 DO RISTF. AGRAVO REGIMENTAL A QUE SE NEGA PROVIMENTO. (STF - AI: 860037 DF , Relator: Min. TEORI ZAVASCKI, Data de Julgamento: 16/10/2014, Tribunal Pleno, Data de Publicação: ACÓRDÃO ELETRÔNICO DJe-217 DIVULG 04-11-2014 PUBLIC 05-11-2014)

Vale salientar que a mera transcrição de ementas não satisfará, a princípio, à

admissibilidade dos embargos de divergência, com hipótese excepcional, no caso da ementa for bem esclarecedora quanto aos detalhes do caso. Nesse caso, sozinha, será suficiente para fundamentar os embargos de divergência. Importante de qualquer forma a juntada do acórdão que se utiliza para comprovar a existência de resultados diversos, para evitar eventual inadmissibilidade do recurso.

\subsection{Do julgamento por turma de tribunal superior: impossibilidade em decisão monocrática}

A decisão impugnável pelos embargos de divergência deve sempre ser do colegiado, não possibilitando a interposição quando ocorrer a decisão monocrática.

Nesta hipótese, quando o relator decidir monocraticamente, o recorrente não pode, precipitadamente, intentar os embargos de divergência, mas sim, o agravo interno para forçar a análise pelo colegiado, julgando de forma colegiada a ação, com o resultado pela denegação. Após o cumprimento deste trâmite, o recurso em questão será cabível:

Trata-se de embargos de divergência opostos de decisão que não conheceu dos embargos de declaração em razão de sua extemporaneidade. Incabível, portanto, o recurso pois oposto contra decisão monocrática. Nesse sentido: "Embargos de 


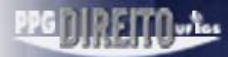

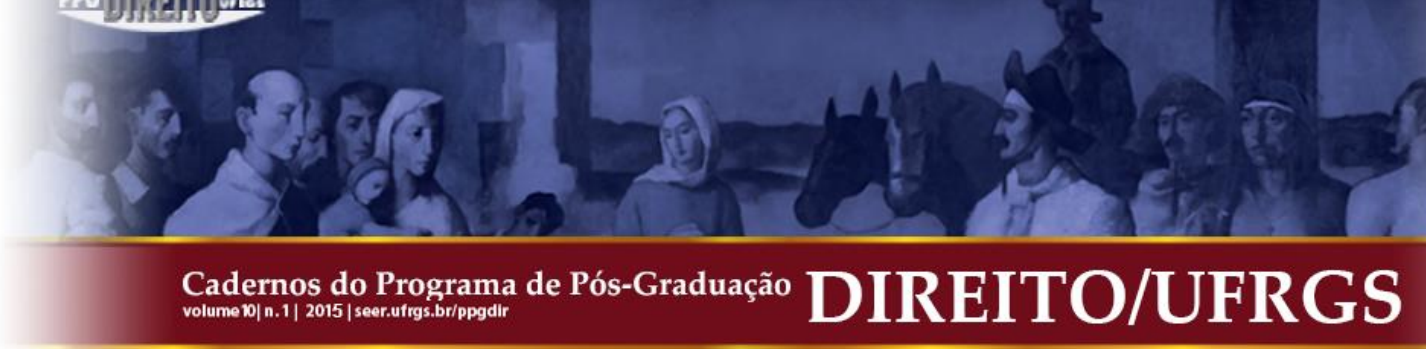

declaração em embargos de divergência em agravo de instrumento convertidos em agravo regimental. Princípio da fungibilidade. Precedentes. 2. São inadmissíveis embargos de divergência opostos contra decisão monocrática. Precedentes. 3. Agravo regimental a que se nega provimento" (AI 767737 - Edv - ED, Rel. Min. Gilmar Mendes). Isso posto, não admito os embargos de divergência, nos termos dos arts. 21, $\S 1^{\circ}$, do RISTF . Publique-se. Brasília, 4 de março de 2015. Ministro Ricardo Lewandowski Presidente(STF - AgR-ED-EDv AI: 841808 PA - PARÁ, Relator: Min. RICARDO LEWANDOWSKI, Data de Julgamento: 04/03/2015)

Uma vez a demanda julgada somente pelo relator de forma monocrática, a prestação jurisdicional, apesar de realizada, não foi realizada em sua plenitude colegiada, tornando incabível os embargos, neste momento. Se a divergência que se busca dirimir deve ser entre turmas, a decisão do relator não corresponde, necessariamente, ao posicionamento do colegiado, da turma.

A interposição dos embargos de divergência nesta situação viola o esgotamento das vias recursais, além de mostrar-se precipitado, pelo fato do agravo interno ainda ser possível.

Com isso, se houver a interposição de embargos de divergência sobre decisão monocrática, impossibilita-se o conhecimento do recurso, resultando numa inadmissibilidade latente por falta de adequação recursal.

A impossibilidade dos embargos de divergência de decisão monocrática não gera um prejuízo ao recorrente, somente demonstra que há todo um caminho processual correto a ser trilhado, com a possibilidade de dirimir posicionamentos ainda no agravo interno. Se com a interposição deste, a divergência prosseguir, cabível serão os embargos de divergência, agora no momento correto.

\subsection{A positivação do efeito interruptivo nos embargos de divergência}

Quando há um julgamento em recurso especial ou em competência originária no STJ cabe recurso extraordinário, se presente a questão constitucional. Um próximo passo normal, diante da recorribilidade dos acórdãos proferidos por este tribunal superior.

Todavia, se, em qualquer destes acórdãos, a parte interessada em pesquisa verificar que além da questão federal, há divergência entre turmas do STJ, o que fazer? Entrar com os embargos de divergência ou com o recurso extraordinário? Uma dúvida pertinente. Muitas vezes, com o receio de perder o recurso, intentavam ambos, os embargos de divergência e o recurso extraordinário, o que por mais que mostrasse o excesso de cautela era um evidente erro no cabimento recursal.

Sempre que há a dúvida entre dois recursos, um interno do tribunal e outro para outro 


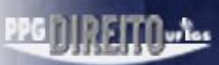 \\ Cadernos do Programa de Pós-Graduação
volume $10 \mid$ n.1| 2015 |seer.ufrgs.br/ppgdir}

tribunal, pertinente intentar o recurso interno, para somente com o julgamento deste interpor. Mas, diferentemente de outros recursos, os embargos de divergência têm característica subjetiva e facultativa, com a necessidade de pesquisa sobre a divergência. Não há a exigência da interposição dos embargos de divergência para esgotar as vias recursais e, somente após, interpor o recurso extraordinário. Se a parte não realizar a pesquisa sobre a divergência ou preferir interpor o recurso ao STF, não há óbice, pode pular a fase dos embargos de divergência, indo diretamente com o recurso extraordinário. É uma clara exceção ao requisito de admissibilidade do esgotamento das vias recursais pelo caráter subjetivo e facultativa dos embargos de divergência.

Para sanar essa dúvida, o código trouxe no artigo 1044, $\S 1^{\circ}$, a estipulação do efeito interruptivo para a interposição dos embargos de divergência. Na realidade, em efeito prático processual, o efeito existia. Com a interposição dos embargos de divergência, evidentemente, se aguardava a resolução deste para, após seu resultado, interpor o recurso extraordinário. Era um efeito interruptivo intrínseco, agora positivado, expressamente.

E a espera para a interposição do recurso extraordinário nesta hipótese já alcançava ambas as partes, de forma a ser "não apenas em favor da pessoa que apresentou a irresignação recursal” (MONTENEGRO FILHO, 2007. p. 167). Agora com a positivação, ainda mais clara a regra sobre a dúvida entre a interposição dos embargos ou recurso extraordinário, tornando evidente que pode ser um e, após a resolução deste, se ainda houver interesse, o outro.

O efeito interruptivo antes era expresso somente para os embargos de declaração, no teor do antigo artigo 538, agora ampliada a sua forma expressa também para os embargos de divergência. Com a interposição deste recurso, os prazos para o próximo recurso ficam interrompido, no aguardo da decisão sobre o recurso, com a publicação do resultado, o prazo é devolvido em sua integralidade para a interposição do recurso subsequente. Intenta-se os embargos de divergência, após seu resultado, se a parte tiver interesse, o recurso extraordinário. Não há a dúvida no momento da interposição dos embargos, deixando o recurso extraordinário para somente após o acórdão sobre a divergência. 


\section{is \\ Cadernos do Programa de Pós-Graduação \\ volume $10 \mid$ n.1| 2015 | seer.ufrgs.br/ppgdir}

2 O INTUITO DA UNIFORMIZAÇÃO DE JURISPRUDÊNCIA

\subsection{Relevância e finalidade}

No tocante a nossa realidade brasileira, o judiciário é acionado em busca de resolução de conflitos, com casos concretos, jurisdicionados dos mais diferentes tipos sociais, necessitando da tutela legal, profundamente esperançosas em busca de soluções jurídicas sedimentadas. Para apaziguar esta situação, bastava que a função da jurisprudência fosse seja efetivada. Essa jurisprudência efetiva consiste, justamente, em interpretar o direito, baseado em casos concretos, aplicando-o a prudência ou sabedoria dos magistrados aos conflitos sociais, objetivando a humanização das leis.

Dessa maneira, ainda que haja inversão na função da atividade jurisprudencial, conforme citação acima mencionada, é necessário que se reconheça a necessidade de jurisprudência no ordenamento jurídico pátrio, ainda mais, que esta seja de fato pacifica, composta por respeito dos julgados superiores, tendo em conta que a jurisprudência diz respeito a decisão reiterada dos tribunais.

Tal é a importância da uniformização da jurisprudência no judiciário brasileiro que o legislador criou vários institutos para pacificação de jurisprudência, inclusive um destes tendo nível recursal, no âmbito dos Tribunais Superiores, os embargos de divergência, conferindo às Cortes Supremas autonomia para sua regulamentação processual, por meio dos seus regimentos internos.

O STJ foi concebido para um escopo especial: orientar a aplicação da lei federal e unificar-lhe a interpretação, em todo o Brasil. Se assim ocorre, é necessário que sua jurisprudência seja observada, para se manter firme e coerente. Assim sempre ocorreu em relação ao STF, de quem o STJ é sucessor, nesse mister. Em verdade, o Poder Judiciário mantém sagrado compromisso com a justiça e a segurança. Se deixarmos que nossa jurisprudência varie ao sabor das convicções pessoais, estaremos prestando um desserviço a nossas instituições. Se nós — os integrantes da corte - não observarmos as decisões que ajudamos a formar, estaremos dando sinal, para que os demais órgãos judiciários façam o mesmo. Estou certo de que, em acontecendo isso, perde sentido a existência da corte. Melhor será extingui-la (AgrReg. nos EmbDiv. no REsp. n. 228.432-rs, corte especial)

Para o bom andamento dos tribunais superiores, para a jurisdição e a sociedade como um todo "é fundamental que o Supremo Tribunal Federal e o Superior Tribunal de Justiça tenham, eles próprios, sua jurisprudência uniformizada, o que justifica, até mesmo, a 


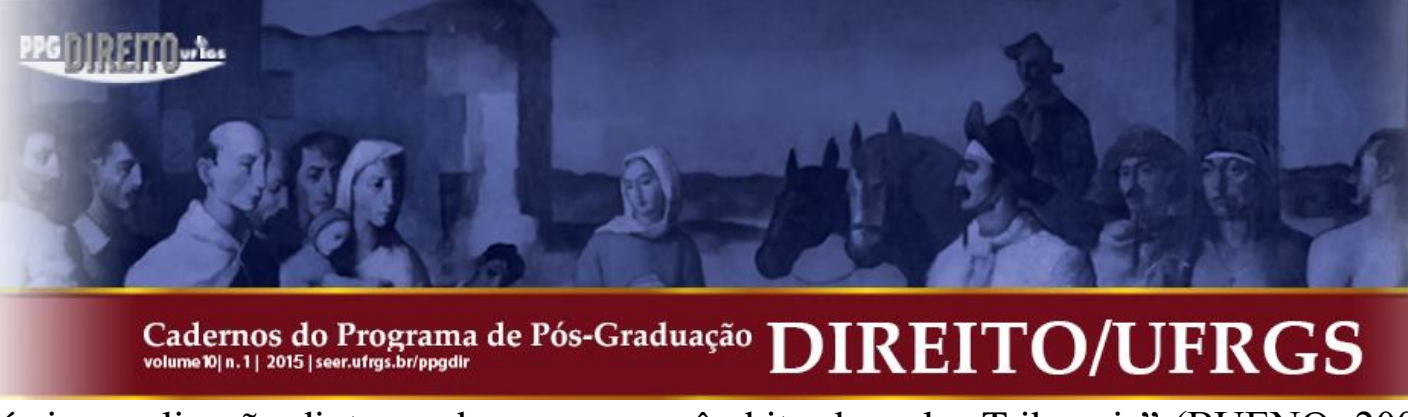

larguíssima aplicação diuturna do recurso no âmbito daqueles Tribunais" (BUENO, 2006, p. 266).

É possível afirmar pela importância da utilização dos embargos de divergência com o fito de unificar a jurisprudência dos tribunais superiores, pela segurança e previsibilidade que os mesmos produzem quanto à interpretação das normas pátrias. Essa é justamente uma das teses defendidas por José Saraiva utilizada na obra de Torreão quando preleciona:

De fato, a segurança e previsibilidade quanto à interpretação das normas nacionais são os efeitos desejados pela coletividade no concernente aos pronunciamentos divulgados pelo Superior Tribunal de Justiça e pelo Supremo Tribunal Federa. (TORREÃO, 2004, p. 30)

E, ainda, quanto maior a unificação, a padronização do pensamento nos Tribunais Superiores, teoricamente, a médio/longo prazo, os recursos sobre cada matéria pacificada serão mais escassos, pela previsibilidade do resultado jurídico sobre a questão, alcançando a afirmação, categoricamente, que os embargos de divergência são imprescindíveis para a realização da justiça nas cortes superiores, ainda mais para cumprir a sua "finalidade de uniformizar o entendimento sobre a lei federal ou a Constituição Federal dentro do próprio tribunal superior" (ARENHART, MARINONI, 2006, p. 382).

\subsection{Meio repressivo para dirimir divergência}

Se os tribunais superiores ao praticarem as suas devidas jurisdições recursais não chegarem a pacificação em determinada matéria, a parte que entender como prejudicada, pode, para dirimir essa divergência, interpor os embargos de divergência. Cada um destes tribunais deve primar pela estabilidade de sua própria jurisprudência, como forma de balizar a vida em sociedade, com confiança jurídica justificada, para realização dos negócios jurídicos inerentes ao cotidiano humano.

Os embargos de divergência são basilares para o combate a uma jurisprudência inconstante, que na primeira batalha perdeu-se em incongruência e pacificação. Dessa forma, o tribunal, se provocado via embargos de divergência, ao julgar a alegada discrepância entre os acórdãos, como o intuito de reprimir o pensamento incoerente. O ideal era trabalhar de forma preventiva, entretanto, uma última saída, uma repressão via embargos de divergência.

Tudo isso, diversas possibilidades e a última delas em âmbito interno e vertical dos tribunais superiores, para não conceber uma verdadeira loteria jurídica, como bem ensina 


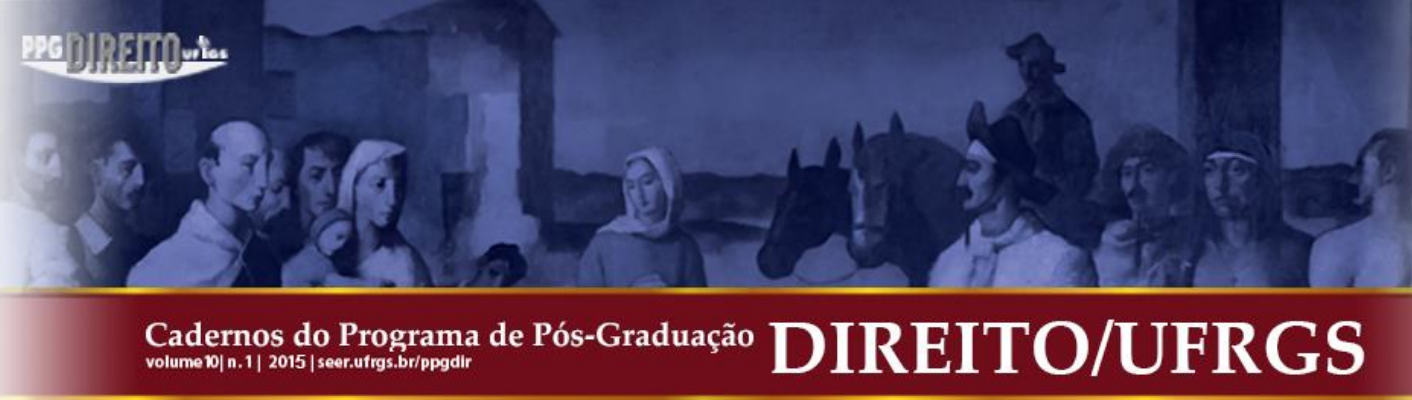

Eduardo Cambi, ao definir de forma clara o tema:

\begin{abstract}
A ideia da jurisprudência lotérica se insere justamente nesse contexto; isto é, quando a mesma questão jurídica é julgada por duas ou mais maneiras diferentes. Assim, se a parte tiver a sorte de a causa ser distribuída a determinado Juiz, que tenha entendimento favorável da matéria jurídica envolvida, obtém a tutela jurisdicional; caso contrário, a decisão não lhe reconhece o direito pleiteado. (2001, p. 111)
\end{abstract}

Uma segunda chance ao jurisdicionado internamente naquele tribunal, de forma individual em seu recurso. Por outro lado, uma mesma segunda chance para o tribunal, com uma finalidade não somente para o recorrente, mas como uma função social, uma pacificação realizada para ajudar a parte, numa análise objetiva e a própria jurisprudência do tribunal, numa análise mais ampla.

\title{
3 A NOVA AMPLITUDE DOS EMBARGOS DE DIVERGÊNCIA
}

A existência da possibilidade de se embargar os acórdãos em Recursos Especial e Extraordinário no CPC-73 recai no julgamento de mérito dos respectivos recursos, necessitando que o recurso ultrapasse a sua própria admissibilidade para que a questão de fundo seja enfrentada e, se houver divergência, possibilitar o cabimento do embargo que suscita a divergência.

A questão sobre a necessidade de se enfrentar o mérito já é matéria pacificada no Superior Tribunal de Justiça, conforme as súmulas 315 e 316, que versaram sobre a matéria do cabimento dos embargos de divergência, conforme se expressam abaixo:

Súmula 315 - "Não cabem embargos de divergência no âmbito do agravo de instrumento que não admite recurso especial"

Súmula 316 - "Cabem embargos de divergência contra acórdão que, em agravo regimental, decide o recurso especial"

O excelso tribunal superior entende atualmente pelo formato recursal disposto no atual código, que somente tem possibilidade de cabimento quando se chega ao mérito do acórdão do Recurso Especial. A súmula 315 refuta justamente a possível admissão de embargos dessa natureza para se discutir matéria de admissibilidade de recurso especial, quando não conhecido o recurso principal, não há possibilidade de embargos para sanar divergência, por mais que haja acórdão paradigma e todos os outros requisitos do recurso de uniformização. Já

Cadernos do Programa de Pós-Graduação em Direito PPGDir./UFRGS | Edição Digital | Porto Alegre | Volume X | Número 1 | 2015 | P.368 - 391 
a súmula 316 trata de outra matéria sobre o cabimento dos mesmos embargos, mas no mesmo sentido, com o intuito de especificar a necessidade do julgamento do próprio recurso especial, o que significa a necessidade do enfrentamento do mérito do recurso para o tribunal superior. Matéria de admissibilidade pode ser discutida por embargos de divergência, porém ainda assim, necessário o enfrentamento do mérito, mesmo que vá se impugnar a admissibilidade, isto que podemos tirar de forma clara e robusta da interpretação das súmulas em questão.

No entanto, com a nova codificação processual quando dispõe sobre a formatação dos embargos de divergência amplia seu cabimento, aumenta a importância do mesmo, abrindo o leque para diversas situações que atualmente não são abarcadas pelo instituto recursal. Mesmo na contramão da celeridade processual e da duração razoável do processo tão almejados no novo ordenamento, os embargos aqui ganham nova vida, mais importância, mais hipóteses.

A redação final do Novo Código de Processo Civil colocou o recurso de embargos na parte final, com a seguinte redação:

Art. 1.043. É embargável o acórdão de órgão fracionário que:

I - em recurso extraordinário ou em recurso especial, divergir do julgamento de qualquer outro órgão do mesmo tribunal, sendo os acórdãos, embargado e paradigma, de mérito;

II - em recurso extraordinário ou em recurso especial, divergir do julgamento de qualquer outro órgão do mesmo tribunal, sendo os acórdãos, embargado e paradigma, relativos ao juízo de admissibilidade;

III - em recurso extraordinário ou em recurso especial, divergir do julgamento de qualquer outro órgão do mesmo tribunal, sendo um acórdão de mérito e outro que não tenha conhecido do recurso, embora tenha apreciado a controvérsia;

IV - nos processos de competência originária, divergir do julgamento de qualquer outro órgão do mesmo tribunal.

Maior alcance, maior discussão, mais importância, diversas novas hipóteses, uma abertura de possibilidades, o que dará aos embargos de divergência novos entendimentos, consequentemente, mais utilização pelas partes do instituto recursal, sendo resultado uma ampliação de decisões embargáveis, "se tornando desnecessárias as discussões sobre tipo da decisão embargada, como da decisão paradigma, se de mérito ou sobre juízo de admissibilidade, se derivadas de recursos excepcionais ou de ações originárias" (LOURENÇO, 2011, p. 1998).

\subsection{A divergência em acórdão de mérito e sobre admissibilidade}

A questão sobre a divergência em acórdão de mérito - inciso I - acaba por ser uma 
reiteração da codificação anterior, sem nenhum reparo a ser realizado, nenhuma mudança drástica ou pertinente sobre o instituto em si. O recurso em seu modus operandi atual já estipula que os acórdãos devem divergir, não estipulando em si quais pontos para que isto aconteça, deixando para a jurisprudência e a doutrina essa visualização.

Na prática, as matérias da divergência atualmente recaem tanto na questão meritória quanto na forma de admissibilidade, somente requisitando que a admissibilidade seja fruto de um recurso conhecido, não podendo ser suscitado em recurso não conhecido, conforme Súmula 315 do STJ. Leonardo Cunha e Fredie Didier Jr já delimitavam que "a divergência pode dizer respeito tanto ao mérito quanto à admissibilidade do especial ou extraordinário" (2013, p. 372).

Com a redação do inciso II, de forma clara a admissibilidade é contemplada para o mérito dos embargos de divergência, positivando o que já se sumulou e admite com naturalidade, porém há a dúvida sobre a manutenção ou não da súmula 315 , no tocante à possibilidade ou não de comparação de recursos que tiveram seu recurso não conhecido. Disposto como "em recurso extraordinário ou em recurso especial, divergir do julgamento de qualquer outro órgão do mesmo tribunal, sendo os acórdãos, embargado e paradigma, relativos ao juízo de admissibilidade," não há positivação sobre a manutenção da necessidade do julgamento ser de mérito, ainda mais quando se fala sobre acórdão embargado e paradigma, não se positiva se tem que enfrentar o recurso excepcional em si, somente há a necessidade de dois acórdãos sobre a matéria de admissibilidade.

Importante a positivação da comparação entre acórdãos com diferentes graus de cognição, fato que não acontece na prática na atualidade, o que dificulta a própria interposição do recurso por uma jurisprudência totalmente defensiva. Cassio Scarpinella Bueno já tinha posicionamento a favor da questão de acórdãos com graus diferentes de julgamento de mérito, pelo fato de muitas vezes o juízo de admissibilidade, adentrar-se na questão meritória, conforme dispõe quando diz que a "questão é tanto mais interessante porque é bastante comum que o acórdão do recurso extraordinário ou especial não conheça do recurso por razões que são, substancialmente, de mérito, por terem, aqueles recursos, 'fundamentação vinculada'” (BUENO, 2011, p. 352).

Apesar de a lacuna deixada pelo legislador neste ponto, creio que a Súmula 315 prevalecerá, extirpando das possibilidades dos embargos de divergência discutir-se somente admissibilidade dos recursos excepcionais, em acórdãos que não enfrentaram o mérito, 


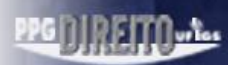 \\ Cadernos do Programa de Pós-Graduação volume $10 \mid$ n.1| 2015 | seer.ufrgs.br/ppgdir \\ DIREITO/UFRGS}

parando somente nesta fase da análise recursal. Seria melhor a positivação neste sentido, para não guardar possibilidades de diferentes análises, mas creio que não esbarre na impossibilidade em questão, possibilitando somente recursos em que se enfrentou o mérito, serem cabíveis dentro dos embargos de divergência. Ainda que este posicionamento seja incongruente com as diretrizes da nova codificação.

O enunciado do Fórum Permanente de Processualistas Civis de forma correta vai em sentido contrário à Súmula 315, para um entendimento que prioriza a amplitude recursal dos embargos de divergência.

Enunciado n. 231 do FPPC: Fica superado o enunciado 315 da súmula do STJ após a entrada em vigor do CPC ("Não cabem embargos de divergência no âmbito do agravo de instrumento que não admite recurso especial)."

Este entendimento permite que se confronte dois acórdãos de recursos especiais ou extraordinários não conhecidos, quando houver divergência entre ambos, o que hoje não é possível por barrar na referida súmula. Se o intuito da nova codificação foi ampliar, coaduno com o entendimento do enunciado, apesar de imaginar que os tribunais devem ir em rumo diverso.

\subsection{A ampliação para a competência originária dos tribunais superiores}

No CPC 73, os embargos de divergência tinham delimitação de cabimento para dirimir divergência quando de decisão de recurso especial ou extraordinário, impossibilitando por falta de positivação a ampliação destes para hipóteses de competência originária ou de outros recursos

O STJ não admitia a interposição de embargos de divergência para alcançar processos que não o recurso especial (no STF o extraordinário). Divergências em âmbito de competência originária ou outros recursos (diferente de REsp ou RE), não serviam para o cabimento dos embargos de divergência, como podemos ver no acórdão a seguir:

AGRAVO REGIMENTAL NOS EMBARGOS DE DIVERGÊNCIA EM RECURSO ESPECIAL. PARADIGMA PROFERIDO EM AÇÃO RESCISÓRIA. INVIABILIDADE. 1. Nos termos do art. 26 do Regimento Interno deste Superior Tribunal de Justiça, os embargos de divergência são cabível para dirimir dissídio de teses entre decisões colegiadas proferidas em sede de recurso especial. 2. Assim, somente se admite com acórdãos paradigmas os proferidos no âmbito de recurso especial e de agravo de instrumento que examine o mérito do apelo, não 


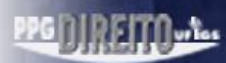

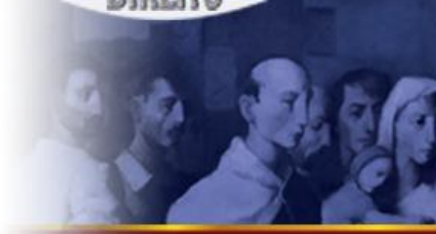 \\ Cadernos do Programa de Pós-Graduação
volume $10 \mid$ n.1| 2015/seer.ufrgs.br/ppgdir}

sendo aptos a tal finalidade os arestos no âmbito de recurso ordinário em mandado de segurança, conflito de competência e ação rescisória. 3. Agravo regimental que se nega provimento. (STJ, AgR nos ERsp 793.405/RJ, Rel. Ministra Mari Thereza de Assis Moura, julgado em 27.04.2011, DJe 9.5.2011.)

O entendimento do novo código passa pela ampliação, na forma de possibilitar dirimir todas as divergências, não importando em quais matérias ou processos sejam, se turmas pensam de forma diferente, importante a possibilidade recursal que preza pela composição de convergência, de dirimir diferenças. Um formalismo da não positivação permite no atual código que turmas pensem diferente sem meios internos para atacar essas discordâncias.

Com a ampliação almejada no novo código de processo civil, § $1^{\circ}$ do artigo 1043, teve a seguinte redação: "poderão ser confrontadas teses jurídicas contidas em julgamentos de recursos e de ações de competência originária."

Dessa forma, o intuito do legislador foi ampliar o leque de possibilidades de dirimir divergências, o que de forma dirigida leva em consideração a busca pela jurisprudência pacificada, pela segurança jurídica das matérias. Não há motivos para admitir pensamentos divergentes em um mesmo tribunal, sendo correta a ampliação do alcance de cabimento dos embargos de divergência possibilitando ao mesmo tempo, a discussão sobre diferentes entendimentos de turmas diversas em processos que iniciam diretamente no tribunal (por alguma competência privilegiada) e o alcance do intuito da nova codificação de ter a jurisprudência estável, integra e coerente, conforme preceitua o artigo 926 do novo código de processo civil.

\subsection{A divergência em direito material ou processual}

No atual código não há positivado sobre os embargos de divergência nenhuma linha sobre a matéria pertinente ao mérito, ao que pode ser impugnado pelos embargos, dessa forma, a jurisprudência e a doutrina que delimitaram o que pode ser pleiteado nos embargos em questão.

Já na nova codificação, preocupou-se com a efetivação da possibilidade de interpor o recurso tanto para as questões materiais, obviamente, quanto para as questões processuais, conforme $\S 2^{\circ}$ do artigo 1043 dispõe: "a divergência que autoriza a interposição de embargos de divergência pode verificar-se na aplicação do direito material ou do direito processual."

Cadernos do Programa de Pós-Graduação em Direito PPGDir./UFRGS | Edição Digital | Porto Alegre | Volume X | Número 1 | 2015 | P.368 - 391 


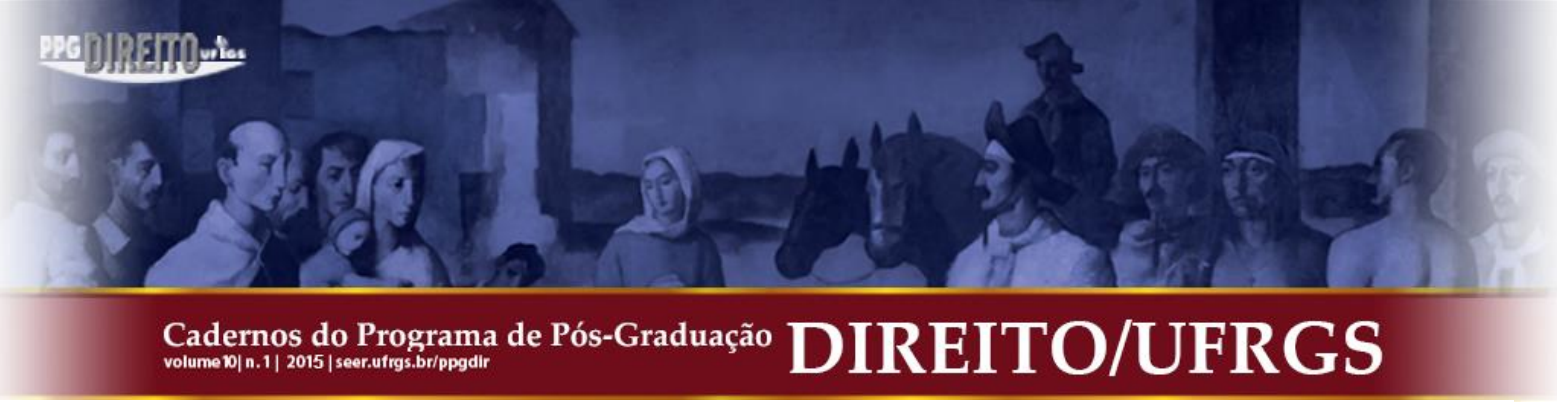

Pode se impugnar tanto o mérito em si dos recursos principais, a resposta pelo qual o recurso excepcional se debruçou na questão de direito evocada, bem como nas discussões de ritos, procedimentos, detalhes processuais que podem interferir no julgamento e servir de base para uma possível divergência. A preocupação neste caso recai pela primazia de possibilitar maiores amplitudes ao recurso, bem como não deixar a cargo da jurisprudência decidir quais as possibilidades de pedidos nos recursos, ao positivar claramente o cabimento sobre direito material ou processual, já delimita o cabimento dos embargos, o que acarreta numa maior credibilidade para a utilização do instituto recursal em qualquer dessas hipóteses. Marinoni e Mitidiero analisando ainda na fase de projeto dessa ampliação, numa comemoração pela possibilidade ampliada das matérias e alcance dos embargos de divergência:

As hipóteses de cabimento dos embargos de divergência [de acordo com o projeto
de Lei 166/2010] agora se baseiam exclusivamente na existência de teses
contrapostas, não importando o veículo que as tenha levado ao SupremoTribunal
Federal ou ao Superior Tribunal de Justiça. Assim, são passíveis de confronto teses
contidas em recursos e ações, sejam as decisões de mérito ou relativas ao juízo de
admissibilidade. (...) Sem que a jurisprudência desses Tribunais esteja internamente
uniformizada, é posto abaixo o edifício cuja base é o respeito aos precedentes dos
Tribunais superiores" (MARIONI, MITIDIEIRO, 2010, p. 215).

O respeito pelos precedentes no novo código é uma busca almejada, uma forma de dar sentido à própria existência do judiciário, manter as suas decisões uniformizadas para uma melhor prestação jurisdicional, com o aumento da amplitude dos embargos de divergência se possibilita uma ferramenta a mais para pacificar matérias, independente de mérito ou admissibilidade, recursos ou ações de competência originária.

A possibilidade de confronto de teses em diferentes formas processuais, analisar de forma comparativa acórdão de recurso com competência originária, não criando uma barreira entre as possibilidades e, sim, uma amplitude maior para o recurso em si, almejando uma melhor prestação para a busca pelo precedente estável, conforme o $\S 1^{\circ}$ do Artigo 1043, que determina que "poderão ser confrontadas teses jurídicas contidas em julgamentos de recursos e de ações de competência originária."

Ainda na possibilidade de ampliação das matérias frutos da comparação entre os acórdãos - recorrido e paradigma - recai na possibilidade aventada e positivada do inciso III do artigo 1043, quando dispõe que pode "divergir do julgamento de qualquer outro órgão do mesmo tribunal, sendo um acórdão de mérito e outro que não tenha conhecido do recurso, embora tenha apreciado a controvérsia". Atualmente, por mais que se possa versar sobre a 


\section{Cadernos do Programa de Pós-Graduação
volume $10 \mid$ n.1| 2015 |seer.ufrgs.br/ppgdir}

controvérsia em questão de admissibilidade, o recurso especial/extraordinário deve ser julgado para chegar nessa possibilidade, o que muda com esse entendimento sobre a comparação entre um acórdão que não se ultrapassou a decisão de admissibilidade, com outro que decidiu o mérito do recurso em si, claro que julgando positiva admissibilidade. Um avanço pertinente em demonstrar que o saneamento da divergência é o ponto forte da amplitude do recurso em questão, o formalismo é escanteado para se chegar de forma mais corriqueira ao destinatário final, ou seja, analisar a divergência entre acórdãos da mesma matéria.

\subsection{A ampliação do cabimento para acórdão da mesma turma}

$\mathrm{Na}$ ótica dos embargos de divergência do CPC 73, era necessário que o acórdão a ser impugnado fosse comparado com acórdão de outra turma daquele tribunal, de forma a realizar-se a similitude fática entre as matérias comparadas, devidamente comprovado no ato do recurso. Mas, aqui, a ênfase recai na necessidade de turmas diferentes na atual codificação, entretanto o novo texto legal possibilita que os acórdãos comparados sejam do mesmo órgão julgador, conforme o $\$ 3^{\circ}$ do artigo 1043, que dispõe que "cabem embargos de divergência quando o acórdão paradigma for da mesma turma que proferiu a decisão embargada, desde que sua composição tenha sofrido alteração em mais da metade de seus membros." (grifo nosso)

O STF já tinha esse entendimento sobre a mudança impactante em suas turmas, o que levava a admitir os embargos de divergência neste caso, com o intuito de proteção ao jurisdicionado que observava a mudança de posicionamento, não por mudança no entendimento do magistrado componente da turma, mas sim da própria composição em si, em quantidade tamanha a representar uma nova turma, não somente a alteração de um membro. A seguir o entendimento do Supremo:

E M E N T A: EMBARGOS DE DIVERGÊNCIA - PRESSUPOSTOS FORMAIS DE SUA UTILIZAÇÃO - CRITÉRIO DA DIVERSIDADE ORGÂNICA (SÚMULA 353/STF) - PADRÃO DE DIVERGÊNCIA QUE EMANOU DA MESMA TURMAQUE PROFERIU A DECISÃO EMBARGADA COMPOSIÇÃO SUBSTANCIALMENTE IDÊNTICA DESSE ÓRGÃO FRACIONÁRIO - EMBARGOS DE DIVERGÊNCIA NÃO ADMITIDOS.- Os embargos de divergência estão sujeitos, dentre os vários pressupostos que lhe condicionam a interposição, à observância do requisito da diversidade orgânica. Esse requisito impõe que o padrão de divergência - para ser validamente invocado 


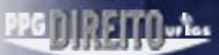

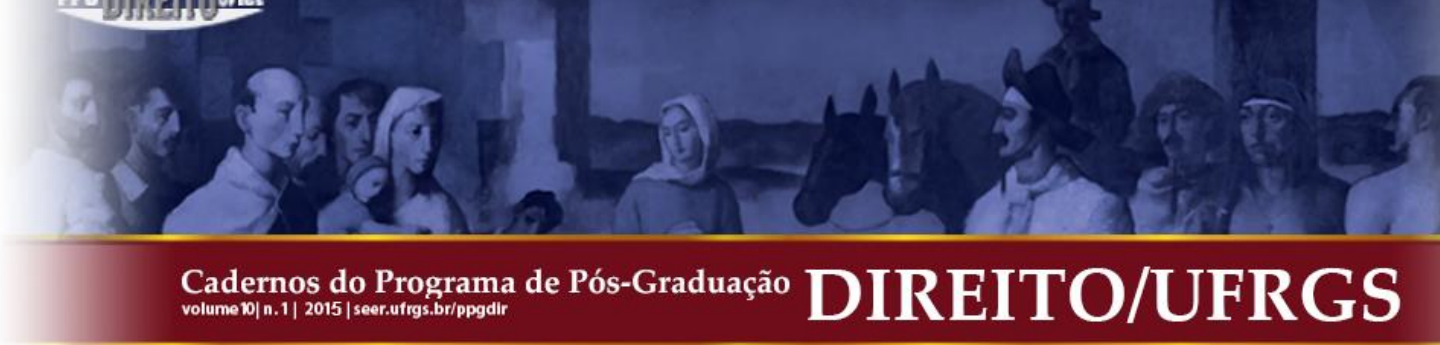

como expressão do dissídio interpretativo -resulte de acórdão emanado, ou do Plenário ou de outra Turma do Supremo Tribunal Federal, pois não se reveste de idoneidade processual, para efeito de demonstração do conflito pretoriano, a indicação de acórdão proferido pela própria Turma de que proveio a decisão contra a qual foram opostos os embargos de divergência(Súmula 353/STF), ressalvada a hipótese excepcional de a Turma haver sofrido substancial modificação em sua composição. Precedentes.- Inocorrência, na espécie, dessa hipótese excepcional, pois os acórdãos em confronto emanaram da mesma Turma cuja composição majoritária - quatro (4) Ministros, no caso - manteve-se substancialmente inalterada. (STF. Pleno. RE-EDv-QO 318469. Rel. Min. Celso de Mello. J. EM 03/10/2002

Assim, o sentido de mesma turma se perde quando este órgão deixa de ter a mesma composição de modo significativo, o que foi positivado como "mais da metade de seus membros", como as turmas dos tribunais superiores têm cinco membros, seria na troca de três dos seus ministros. No entendimento de Barbosa Moreira a hipótese era plausível, porém impunha em seu pensamento que a mudança deveria recair sobre os votos ganhadores daquela decisão, "notadamente a da maioria vitoriosa, de um para outro julgamento" (2005, p. 626).

O Novo Código não impôs assim a necessidade de se verificar qual ministro teria realizado o voto vencedor ou perdedor no acórdão paradigma, o critério utilizado para a positivação findou-se na maneira fácil, objetiva de verificação, mais da metade dos membros mudando a composição daquele órgão fracionário já importa em cabimento dos Embargos de Divergência, uma verdadeira positivação do entendimento do STF.

Entretanto, nesta hipótese o ônus da comprovação da mudança recairá sobre quem? O acórdão em si é público e a verificação da ata de julgamento não é das mais difíceis, porém, o interesse na demonstração do cabimento e da verificação da hipótese deste $\S 3^{\circ}$ será do recorrente, que além da própria comprovação de existência do acórdão paradigma, terá o ônus de se comprovar a alteração da composição em quantidade maior da metade da composição.

\subsection{A necessidade de fundamentação para negativa por distinção}

O novo ordenamento processual tem uma tendência de positivar aprimoramentos no quesito fundamentação das decisões, criar critérios objetivos onde dantes ficava a livre exercício do juízo. Há assim o intuito de contemplar o jurisdicionado com o máximo de informações jurídicas possíveis sobre a decisão no enfrentamento da matéria.

No tocante aos embargos de divergência a fundamentação não foi esquecida, tendo o $§$ $5^{\circ}$ do artigo 1043, positivado da seguinte maneira: "é vedado ao tribunal inadmitir o recurso com base em fundamento genérico de que as circunstâncias fáticas são diferentes, sem 


\section{(xa) Rigrigum

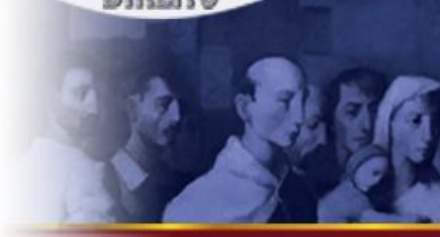 \\ Cadernos do Programa de Pós-Graduação
volume $10 \mid$ n.1| 2015/seer.ufrgs.br/ppgdir}

demonstrar a existência da distinção.”

Nos embargos de divergência almeja-se a comparação de acórdãos com resultados diferentes, porém com similitudes fáticas, baseando-se o mérito recursal na existência de entendimentos diversos sobre mesma matéria e hipótese fática idêntica. Caso o tribunal verifique que os fatos são diversos e somente assuntos diferentes entre os acórdãos, não pode simplesmente alegar "circunstâncias fáticas diferentes", haverá necessidade de distinguir de forma exaustiva as diferenças entre o fato do acórdão recorrido daquele do acórdão paradigma.

O dispositivo em questão está em harmonia com o artigo 489, § $1^{\circ} \mathrm{em}$ seus incisos IV e V quando se trata da necessidade de enfrentar todos os argumentos das partes, realmente responder jurisdicionalmente o questionado processualmente, não podendo somente invocar súmulas ou precedentes, devendo diferenciar o caso de forma clara quando a negativa recursal se saber a distinção dos fatos recursais. Abaixo, os incisos supracitados:

$[\ldots]$

IV - não enfrentar todos os argumentos deduzidos no processo capazes de, em tese, infirmar a conclusão adotada pelo julgador;

$\mathrm{V}$ - se limitar a invocar precedente ou enunciado de súmula, sem identificar seus fundamentos determinantes nem demonstrar que o caso sob julgamento se ajusta àqueles fundamentos. [...]

A preocupação é pertinente nesta positivação, uma prática nefasta dos tribunais em ao reconhecer diferenças somente dizer que existem, sem enumerá-las e deixá-las expostas de forma clara. O intuito dessa fundamentação exaustiva será o dever de informar, deixando a parte cientificada de seus direitos e do resultado da demanda, de forma que "não deve ser observada apenas para justificar racionalmente a decisão do juiz, mas também para demonstrar, não apenas que ele tomou ciência de todo o conteúdo do processo e de todas as questões nele suscitadas, mas também que todas elas foram devidamente apreciadas" (GRECO, 2010, p. 271).

O quanto mais claro uma questão processual ou material é enfrentada, menos dúvida para o jurisdicionado. 


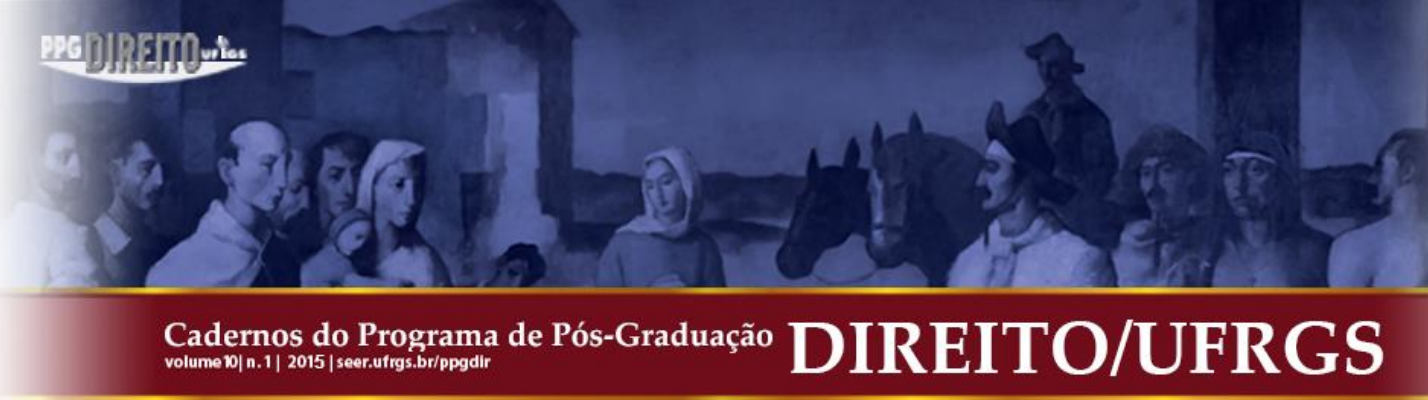

CONCLUSÃO

Ao longo dos tempos o homem tem procurado diminuir e, porque não dizer, eliminar as diferenças sociais que o cercam. Para tanto, muito tem empreendido com o fito de alcançar esse objetivo, com dispositivos legais em busca de uma melhor prestação jurisdicional ao cidadão. Entretanto, ainda muito falta para se alcançar a excelência nesse mister.

Deve-se levar em conta que o atual Código de Processo Civil brasileiro é de 1973. Esculpido dentro de um contesto histórico específico, em auge da ditadura militar. Entretanto, vale ressaltar que muito se tem feito para minimizar esta discrepância histórico-social adequando-o aos nossos dias e costumes. Já o novo Código de Processo Civil, advindo do PL 8046/10, recentemente aprovado, tem um viés totalmente democrático, independente de seu resultado final e prático, o adjetivo democrático é o que melhor funciona para explicá-lo.

O intuito da nova codificação recaiu na preservação da jurisprudência, no respeito, coerência, integridade e estabilidade desta. A necessidade de se almejar a pacificação é latente, posto que atualmente existem mais de 100 milhões de ações que estão tramitando na justiça para serem julgadas por aproximadamente18 mil juízes.

Todo este arrazoado histórico tem por finalidade demonstrar a importância do sistema recursal, ressaltando-se, em especial, os Embargos de Divergência, que apesar de relegados em importância e estudo, têm um relevante papel na jurisprudência recursal brasileira. Com a nova legislação processual a amplitude e a importância tendem a aumentar, a sua utilização que outrora vinha de um emaranhado de dúvidas jurisprudenciais e súmulas constantes, sentirão a positivação ampla do instituto, aumentando possibilidades e caminhos para sua utilização.

Maiores possibilidades, mais regras, maior flexibilidade para o seu cabimento, uma busca por deixar mais clara e certa as formas de manejamento recursal, para que cumpra a sua real função, impor ao tribunal superior em questão a necessidade da uniformização de sua jurisprudência interna.

Como dar-se-ia a resolução de um conflito em que não houvessem os embargos de divergência, que objetivam a uniformização das decisões tomadas pelos Tribunais Superiores e, portanto, o reexame da decisão prolatada pelo juízo a quo? Aonde seria buscada essa solução se não houvesse a esfera superior que se utiliza dos embargos de divergência para 


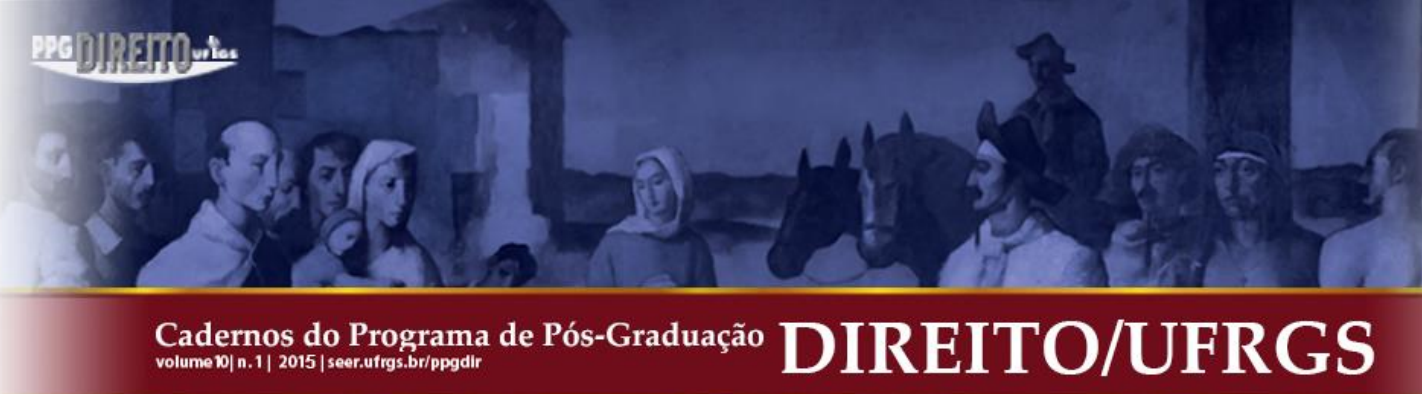

apaziguamento das decisões? Que parâmetro seria utilizado para decisões divergentes? Ter-seia solução equânime para os conflitos?

Por fim, conclui-se que, apesar das dificuldades existentes no judiciário concernente ao uso dos embargos de divergência no sistema recursal brasileiro, eles são extremamente importantes para a solução de divergência no âmbito Superior, realizando a sua função precípua: uniformizar a jurisprudência entre as Turmas julgadoras das Cortes Superiores e, conseguinte, estabelecer diretrizes para julgar as instâncias infraconstitucionais do Poder Judiciário e louvável a decisão do legislador em aumentar o alcance recursal, possibilitando maiores voos para os embargos de divergência.

\section{REFERÊNCIAS}

AMENDOEIRA Jr., Sidnei. Manual de Direito Processual Civil. Editora Saraiva. São Paulo, 2012. Vol II.

ARENHART, Sérgio Cruz; MARINONI, Luiz Guilherme. Manual de Processo Civil. 5. ed. São Paulo: Editora Revista dos Tribunais, 2006.

BRASIL. Código de Processo Civil. Lei no 13.105, de 16 de março de 2015

.Código de Processo Civil. Lei 5.869 de 11 de janeiro de 1973.

. Código de Processo Civil. 1939.

. Constituição da República Federativa do Brasil de 1988.

PL8.046/10. Novo Código de Processo Civil.

. Regimento Interno do Superior Tribunal de Justiça, de 22 de junho de 1989.

. Regimento Interno do Supremo Tribunal Federal, de 27 de outubro de 1980.

. Lei $n^{\circ}$ 8.950, de 07 de Dezembro de 1994. 
. Lei $n^{\circ}$ 623, de 19 de Fevereiro de 1949.

Superior Tribunal de Justiça. Site do Superior Tribunal de Justiça. Disponível em: <www.stj.jus.br/>. Acesso em: 13 mar. 2015.

. Supremo Tribunal Federal. Site do Supremo Tribunal Federal. Disponível em: <www.stf.jus.br/>. Acesso em: 13 mar. 2015.

BUENO, Cassio Scarpinella. Curso Sistematizado de Direito Processual Civil. $3^{\text {a }}$ Ed. São Paulo: Saraiva, 2011, Vol. 5.

CÂMARA, Alexandre Freitas. Lições de Direito Processual Civil. $15^{\mathrm{a}}$ ed., revista e atualizada. Rio de Janeiro: Lumen Juris, 2008.

CAMBI, Eduardo. Jurisprudência Lotérica. Revista dos Tribunais, São Paulo, ano 90, v. 786, abr. 2001.

DICIONÁRIO Informal. Embargo. Disponível em: <www.dicionarioinformal.com.br/embargo/>. Acesso em: 22 mai. 2015.

DIDIER JR, Fredie; CUNHA, Leonardo Carneiro da. Curso de Direito Processual Civil. Meios de Impugnação às Decisões Judicias e Processo nos Tribunais, vol. 3, $11^{\mathrm{a}}$ ed., revista, ampliada e atualizada. Salvador: Editora Jus Podium, 2013.

FIGUEIREDO, Simone Diogo Carvalho; MONTANA DE SÁ, Renato. Direito processo civil 2. São Paulo: Coleção OAB Nacional primeira fase, 2009.

GONÇALVES, Marcus Vinicius Rios. Direito Processual Civil Esquematizado. São Paulo: Saraiva, 2011.

GRECO, Leonardo. Instituições de Processo Civil. Vol. II. Rio de Janeiro: Forense, 2010. 
